\title{
Changes of the equilibrium-line altitude since the Little Ice Age in the Nepalese Himalaya
}

\author{
Rijan Bhakta KAYASTHA, ${ }^{1 *}$ Sandy P. HARRISON ${ }^{1,2}$ \\ ${ }^{1}$ Max Planck Institute for Biogeochemistry, PO Box 100164, D-07741 Jena, Germany \\ E-mail: rijan@ku.edu.np \\ ${ }^{2}$ School of Geographical Sciences, University of Bristol, University Road, Bristol BS8 1SS, UK
}

\begin{abstract}
Changes of the equilibrium-line altitude (ELA) since the end of the Little Ice Age (LIA) in eastern Nepal have been studied using glacier inventory data. The toe-to-headwall altitude ratios (THARs) for individual glaciers were calculated for 1992, and used to estimate the ELA in 1959 and at the end of the LIA. THAR for debris-free glaciers is found to be smaller than for debris-covered glaciers. The ELAs for debris-covered glaciers are higher than those for debris-free glaciers in eastern Nepal. There is considerable variation in the reconstructed change in ELA ( $\triangle E L A)$ between glaciers within specific regions and between regions. This is not related to climate gradients, but results from differences in glacier aspect: southeast- and south-facing glaciers show larger $\triangle E L A s$ in eastern Nepal than north- or west-facing glaciers. The data suggest that the rate of ELA rise may have accelerated in the last few decades. The limited number of climate records from Nepal, and analyses using a simple ELA-climate model, suggest that the higher rate of the $\triangle$ ELA between 1959 and 1992 is a result of increased warming that occurred after the 1970s at higher altitudes in Nepal.
\end{abstract}

\section{INTRODUCTION}

There is widespread evidence that glaciers are retreating in many mountain areas of the world. Haeberli and Beniston (1998) reported that since 1850 the glaciers of the European Alps have lost about $30-40 \%$ of their surface area and about half of their volume. Similarly, glaciers in several regions of central Asia have been retreating since the 1950s (Fitzharris, 1996; M. Meier, unpublished information). Glacial retreat is also prevalent in the higher elevations of the tropics. Glaciers on Mount Kenya and Kilimanjaro have lost $>60 \%$ of their area in the last century (Hastenrath, 1991; Hastenrath and Greischar, 1997), and accelerated retreat has been reported for the Peruvian Andes (Kaser and Osmaston, 2002; E. Mosley-Thompson, unpublished information). Although there is considerable variability at regional and local scales, and over shorter time periods, the overall global signal shows mass loss and retreat of glaciers during the last century. Glacier retreat during the last century is probably a reflection of post-industrial warming (Houghton and others, 2001). For the period 1884-1978, the mean global glacial retreat corresponds to a calculated warming of about $0.7^{\circ} \mathrm{C}(100 \mathrm{a})^{-1}$ (Oerlemans, 1994). Global compilations indicate that the wastage of mountain glaciers during the last century has raised sea level by $0.2-0.4 \mathrm{~mm} \mathrm{a}^{-1}$, or roughly $20 \%$ of the observed change (Warrick and others, 1996; Dyurgerov and Meier, 1997).

Several studies in the Himalaya have found that individual glaciers have retreated considerably since the 1970s (Higuchi and others 1980; Miller, 1989; Miller and Marston, 1989; Yamada and others, 1992; Kadota and others, 1993; Fujita and others, 1998, 2001). The aim of the present study is to summarize evidence from Nepal for changes in the equilibrium-line altitude (ELA) since the beginning of the industrial period, which corresponds roughly to the end of

*Present address: Kathmandu University Dhulikhel, Kavre, PO Box 6250 Kathmandu, Nepal. the Little Ice Age (LIA) in this region. We compare these changes in ELA ( $\triangle E L A)$ with changes estimated for recent decades, and investigate the possible causes of the observed spatial and temporal patterns in $\triangle E L A$.

\section{THE STUDY AREA}

The study area lies in the central part of the Hindu KushHimalaya, in the eastern part of Nepal. The Hindu KushHimalayan range extends $>3500 \mathrm{~km}$, from Burma in the east to Afghanistan in the northwest. It comprises several ranges including the Siwaliks, the Lesser Himalaya, the Greater Himalaya, the Karakoram mountains and the Hindu Kush. These mountain ranges are influenced by two major climatic systems: the mid-latitude westerlies and the South Asian monsoon. The South Asian summer monsoonal influence is greatest in the eastern and central part of the Hindu KushHimalayan range (Bhutan, Nepal, Garhwal). The western parts of the Hindu Kush-Himalaya (Ladakh, Karakoram, Hindu Kush) have a winter precipitation maximum due to the influence of winter westerly winds bringing moisture from the Mediterranean, Black and Caspian Seas, and are climatically similar to mid-latitude mountain ranges.

Individual valleys within the eastern part of the Himalayan range have distinctive local circulation and climatic conditions, depending on elevation, area, orientation and whether they are glaciated. The airflow is driven by the prevailing summer monsoon, but mountain and valley breezes generally prevail on a daily scale (Yasunari, 1976). Summer precipitation is the main source of annual accumulation on the eastern Himalayan glaciers. Monsoon precipitation is greater in the eastern and southern parts of the Himalayan range than in the western or northern parts (Eguchi, 1994). The monsoonal regime not only limits accumulation but also decreases ablation because monsoon precipitation is accompanied by cloudy weather which decreases air temperature during the melt season. Ablation is also reduced because the deposition of new snow on the 


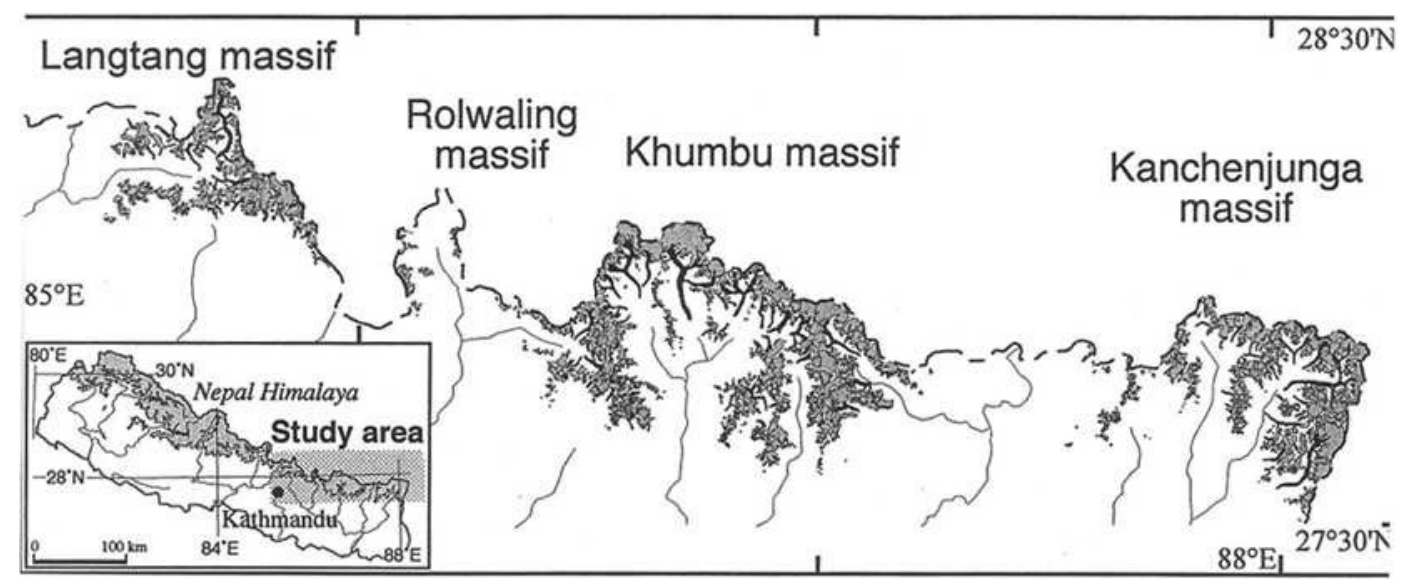

Fig. 1. Location map of studied glacierized regions in Nepal.

glaciers results in increased albedo, and thus lowers insolation receipts. The glaciers of the eastern Himalaya can be classified as 'summer-accumulation type' in the scheme developed by Ageta and Higuchi (1984).

\section{SOURCES OF GLACIER INFORMATION}

Glaciological observations in Nepal are very scarce, and ELA has only been estimated for a few glaciers. Asahi (1999) has made the first compilation of information about the glaciers in the eastern part of Nepal. This inventory (Asahi, 1999; personal communication from K. Asahi, 2003) is based on topographic maps on a scale of 1 in to 1 mile (i.e. $1: 63$ 360) published in 1963 by the Survey of India and at a scale of 1:50000 published in 1997 by the Department of Survey, Nepal. The 1963 topographic map was based on aerial photographs taken in 1958/59, and the 1997 map was based on aerial photographs taken in October 1992. The inventory contains information on the surface area, aspect, highest and lowest elevations in 1992, and the ELA in 1992 for 1116 individual glaciers. It also contains information about the vertical retreat of the terminus between the end of the LIA and 1959 for these glaciers. The 1992 ELA was estimated based on snowline altitudes identified on the October 1992 photographs. In the present study, it is assumed that the snowline equals the ELA for that year. The terminal position of glaciers at the end of the LIA was identified by the presence of moraine, and the terminal positions of glaciers in 1959 and 1992 were identified from the topographic maps and aerial photographs, respectively (Asahi, 1999).

\section{METHODS AND ANALYSES}

The inventory contains glacier information from easternmost (Kanchanjunga Himal) to central Nepal (Langtang Himal). For analytical purposes, we have divided this area into four geographical regions: Kanchanjunga, Khumbu, Rolwaling and Langtang (Fig. 1). When it is necessary to analyze data from the four regions together, we refer to the area collectively as eastern Nepal.

The inventory does not contain all the necessary data for every glacier. Only those glaciers that have both a 1992 ELA estimate and estimates of the vertical retreat of the terminus since either the end of the LIA or 1959 are used in this study.
Glaciers with a surface area less than $0.2 \mathrm{~km}^{2}$ are excluded from the analysis since the toe-to-headwall altitude ratio (THAR) method does not work for these glaciers. There are many debris-covered glaciers in the Himalaya. Debris cover profoundly influences ablation and its spatial variations: very thin debris cover tends to accelerate ablation by lowering albedo, whereas debris thicker than a few $\mathrm{cm}$ tends to insulate the underlying ice, inhibiting ablation (Østrem, 1959; Nakawo and Young, 1982; Kayastha and others, 2000). Consequently, glaciers with thick debris cover tend to have relatively large ablation areas, with reversed ablation gradients in their lower reaches. This introduces large variations in mass-balance characteristics and ELAs relative to glacier geometry (Benn and others, 2005). In general, the THAR method to estimate ELA is questionable for debriscovered glaciers. Therefore, we exclude debris-covered glaciers in this paper.

The ELAs for the end of the LIA and 1959 were estimated using the THAR method. The THAR method (Meierding, 1982) assumes that the ELA can be approximated by some constant ratio between the lowest and highest (headwall) elevations of the glacier. The ELA lies midway, in altitude, between the head of the glacier $\left(A_{\mathrm{h}}\right)$ and the terminus $\left(A_{\mathrm{t}}\right)$. The ELA was computed using

$$
\mathrm{ELA}=A_{\mathrm{t}}+\operatorname{THAR}\left(A_{\mathrm{h}}-A_{\mathrm{t}}\right) .
$$

The THAR was calculated for each glacier based on the data (lowest and highest elevations, estimated ELA) in 1992. The calculated THAR for 1992 was used to estimate the ELA in 1959 and at the end of the LIA. The lowest elevation at the end of the LIA (or in 1959) was derived by adding the vertical retreat of the terminus between the LIA and 1992 (or 1959 and 1992) to the lowest elevation of the glacier in 1992. The mean THAR for the basin is used for those glaciers for which there is no information on the 1992 ELA but the vertical retreat of the terminus is known. Glaciers whose estimated 1992 ELAs lie above the headwall elevation were excluded from further analysis. The highest altitude of the glacier at the end of the LIA and in 1959 is assumed the same as in 1992 in the calculation of the ELA. This may lead to an underestimation of the highest altitude at both time periods: the highest altitudes in 1992 were around $6000 \mathrm{~m}$, but this may be lower than during earlier periods because of loss through ice ablation and glacier dynamics.

The LIA is generally assumed to date to AD 1550-1850 (Bradley and Jones, 1992). Previous studies of former glacial 
Table 1. ELA parameters for the end of the LIA, 1959 and 1992 for different regions of eastern Nepal. The number of glaciers is given in parentheses

\begin{tabular}{|c|c|c|c|c|c|c|c|c|}
\hline & \multicolumn{3}{|c|}{ Mean ELA } & \multirow[t]{3}{*}{ THAR (1992) } & \multicolumn{2}{|c|}{ Mean $\Delta \mathrm{ELA}$} & \multicolumn{2}{|c|}{ Mean rate of change of $\Delta E L A$} \\
\hline & LIA & 1959 & 1992 & & LIA to 1959 & 1959-92 & LIA to 1959 & 1959-92 \\
\hline & $\mathrm{m}$ & $\mathrm{m}$ & $\mathrm{m}$ & & $\mathrm{m}$ & $\mathrm{m}$ & $\mathrm{ma}^{-1}$ & $\mathrm{ma}^{-1}$ \\
\hline Kanchanjunga & $5335 \pm 224(28)$ & $5351 \pm 185(23)$ & $5388 \pm 204(28)$ & $0.61 \pm 0.11$ & $47 \pm 32(21)$ & $18 \pm 13(19)$ & $0.33 \pm 0.22$ & $0.56 \pm 0.41$ \\
\hline Khumbu & $5479 \pm 120(29)$ & $5551 \pm 127(31)$ & $5608 \pm 120(25)$ & $0.64 \pm 0.12$ & $54 \pm 50(24)$ & $29 \pm 35(20)$ & $0.38 \pm 0.34$ & $0.87 \pm 1.06$ \\
\hline Rolwaling & $5311 \pm 158(15)$ & $5263 \pm 86(11)$ & $5380 \pm 127(25)$ & $0.63 \pm 0.10(20)$ & $80 \pm 37(7)$ & $43 \pm 29(10)$ & $0.59 \pm 0.26$ & $1.00 \pm 0.88$ \\
\hline Langtang & $5227 \pm 108(21)$ & $5250 \pm 115(6)$ & $5310 \pm 74(21)$ & $0.62 \pm 0.11(21)$ & $51 \pm 33(5)$ & $19 \pm 15(5)$ & $0.35 \pm 0.23$ & $0.59 \pm 0.44$ \\
\hline Eastern Nepal & $5350 \pm 186(93)$ & $5413 \pm 188(71)$ & $5435 \pm 181(100)$ & $0.63 \pm 0.11$ & $54 \pm 41(57)$ & $25 \pm 26(54)$ & $0.38 \pm 0.29$ & $0.76 \pm 0.79$ \\
\hline
\end{tabular}

extents in eastern Nepal have been limited to a few regions, and information about the exact dating of the LIA is very limited. Shiraiwa and Watanabe (1991) identified the inner moraine complex of the Yala I Stage in the Langtang valley, Nepal, as having been formed during the LIA, but they could not obtain radiometric dates on this moraine complex. They dated moraines associated with the subsequent advance (Yala II) in the Lirung valley to around AD 1910. Ono (1985) reconstructed the timing of recent fluctuations of Yala Glacier itself using annual moraine ridges. He reported a date of AD 1815 for the last advance of Yala Glacier in the LIA. We therefore take AD 1815 as corresponding to the end of the LIA in eastern Nepal, and use this date to calculate retreat rates. Tree-ring reconstructions from Nepal (Cook and others, 2003) show a gradual increase in temperature after AD 1825, and thus support the suggestion that the LIA was over by this time. We assume that the age for the termination of the LIA in the Langtang region can be used for other regions of Nepal.

\section{RECONSTRUCTED CHANGES IN ELAs AND $\triangle$ ELAs}

The calculated mean ELAs for the end of the LIA, 1959 and 1992, and the 1992 THARs are shown in Table 1. The ELAs, $\triangle E L A s$, rate of change of $\triangle E L A s$ and THARs are shown for the four regions separately, as well as for eastern Nepal as a whole. The error margins are shown by one standard deviation.

The range of THARs found in eastern Nepal is large. However, the extreme THAR values are found in sites where either the modern ELA is beyond the glacier location or there are large discrepancies between the estimated ELA and the estimated vertical retreat of the glacier. A more realistic estimate of the range in THAR is $0.4-0.9$. There is no difference in the mean THAR (or standard deviation) between regions, however, so this variability must reflect local differences in, for example, aspect or valley topography, rather than climatic trends across the region. A similar conclusion is reached by examining the 1992 ELA. The highest and lowest mean ELAs are found in the Khumbu and Langtang regions, respectively. There is no systematic trend in ELA between regions. Although the amount of Indian summer monsoon precipitation decreases from east to west and from south to north in the main Himalayan range, the east-west differences across eastern Nepal are negligible. Again, this supports the idea that both withinregion and apparent between-region differences reflect local differences rather than any systematic change in climate across the region.

The calculated mean $\triangle$ ELAs for the periods between the end of the LIA and 1959, and 1959-92 are derived from the available data (Table 1). There are some discrepancies in the calculated mean ELAs and $\triangle E L A s$. The calculated mean 1959 ELA in Rolwaling is lower (5263 m) than the mean LIA ELA $(5311 \mathrm{~m})$, although the mean $\triangle \mathrm{ELA}$ between the end of the LIA and 1959 is $80 \mathrm{~m}$. This is due to lack of information about the post-1959 vertical retreat of the terminus of some glaciers in the inventory, and consequently higher-thanaverage 1959 ELAs. This is much improved when all glaciers in eastern Nepal are considered. The mean ELAs and $\Delta$ ELAs are also calculated only with those glaciers which have all three ELAs and $\triangle$ ELAs. When these two sets of results are compared, the maximum difference in ELA is $12 \mathrm{~m}(0.2 \%)$ at the end of the LIA, and the maximum difference in $\triangle E L A$ is $4 \mathrm{~m}(16 \%)$ between 1959 and 1992 . This verifies that although there is a small discrepancy in some regions, the calculated values represent mean ELAs and $\triangle E L A s$ in eastern Nepal.

The mean $\triangle E L A$ between the LIA and 1959 across eastern Nepal is $54 \mathrm{~m}$ (Table 1). The $\triangle \mathrm{ELA}$ in the subsequent period (1959-92) is $25 \mathrm{~m}$. Assuming the LIA ends in AD 1815, the average rate of ELA rise from 1815 to 1959 for eastern Nepal is $0.38 \mathrm{~m} \mathrm{a}^{-1}$, compared to an average rate of $0.76 \mathrm{~m} \mathrm{a}^{-1}$ between 1959 and 1992. The rate of change of $\Delta E L A$ during recent decades differs significantly from that in the earlier period in eastern Nepal. Thus, our data suggest that the glaciers of eastern Nepal have been retreating more rapidly in recent decades than in the earlier part of the century.

We have examined the relationships between the vertical shift of the ELA and headwall elevation, glacier area and aspect. There is no correlation between the $\triangle E L A$ and either headwall elevation or glacier area in all regions for all three periods. The correlation is also very low when the data are pre-divided according to aspect. However, intra-regional variability in $\triangle$ ELA between the LIA and 1992 is related to glacier aspect. Aspect analysis of $\triangle$ ELA between the LIA and 1992 shows that glaciers on west- and south-facing slopes have larger $\triangle E L A s$ than glaciers facing southeast and northwest in the Kanchanjunga region; south- and southwest-facing glaciers show larger $\Delta$ ELAs than glaciers facing west in the Khumbu region; northeast-facing glaciers show larger $\triangle$ ELAs than glaciers facing east and northwest in the Rolwaling region; and southeast- and northeast-facing glaciers show larger $\Delta$ ELAs than glaciers facing south and west in the Langtang region. When all regions are considered, 

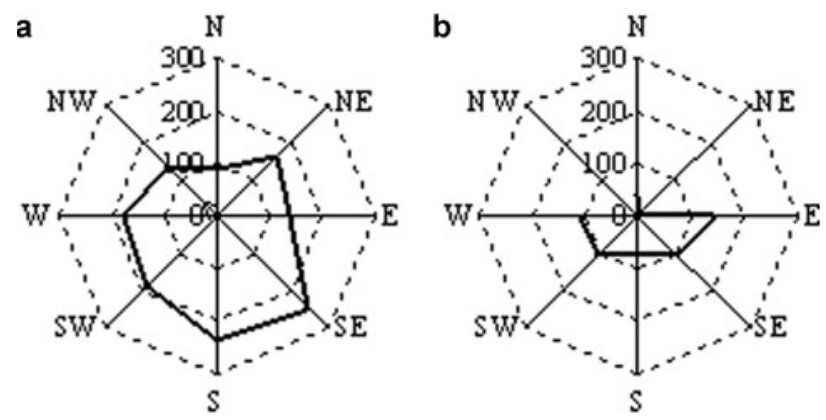

Fig. 2. Radar plots of the range of $\triangle E L A(m)$ between the end of the LIA and 1992 by aspect for (a) debris-free and (b) debris-covered glaciers in eastern Nepal. Thin lines represent minimum values, and thick lines maximum values.

southeast- and south-facing glaciers show larger $\triangle E L A s$ between the end of the LIA and 1992 than glaciers facing southwest and west in eastern Nepal (Fig. 2). Thus, in eastern Nepal, southeast- and south-facing glaciers have retreated most in the recent past. Such uneven changes of the ELA with respect to aspect are probably due to local variation in precipitation and solar radiation.

\section{INFERRED CAUSES OF REGIONAL CHANGES IN $\triangle$ ELA}

Instrumental records of temperature (Fig. 3) between 1879 and 1977 and precipitation (Fig. 4) between 1851 and 1950 are available from the Indian Embassy in Kathmandu, Nepal (Nepal: Department of Irrigation, Hydrology and Meteorology, 1977; World Data Center for Paleoclimatology, Boulder, USA: ftp://ftp.ncdc.noaa.gov/pub/data/paleo/ treering/reconstructions/asia/nepal/kathmandu_temp.txt). The temperature data prior to 1897 are not considered reliable (Cook and others, 2003), in part because of an abrupt temperature jump before 1893 and in part because some data are missing. Precipitation data from Kathmandu airport (published by the Department of Hydrology and Meteorology (DHM), Nepal, in different years), which is $\sim 2 \mathrm{~km}$ from the Indian Embassy station, are used for the period 1968-96. Shrestha and others (1999) have summarized the data from four other stations in the Kathmandu valley with records between 1971 and 1994, and derived a single composite Kathmandu temperature record from 1921 to 1994. There is a single 13 year record from a highelevation site (Kyangjing hydro-meteorological station (3920 ma.s.l.)) in the Langtang valley, published by the DHM in 1993 and thereafter (Nepal: DHM, 1993).

The precipitation records both from the Kathmandu region (Fig. 4) and from the Langtang valley (Fig. 5) show no significant trend over the recorded period. This suggests that it is highly unlikely that the reconstructed changes in ELA have been caused by changes in precipitation. On the other hand, the temperature records show a warming trend through the historical period. The record from Kathmandu, for example, shows an air-temperature increase of $0.27^{\circ} \mathrm{C}$ between 1897 and 1977 and of $\sim 1^{\circ} \mathrm{C}$ between 1975 and 1994 (Shrestha and others, 1999).

There are insufficient climate records from the glacierized regions of the eastern Himalaya to be able to investigate how far the observed spatial and temporal differences in $\triangle E L A$

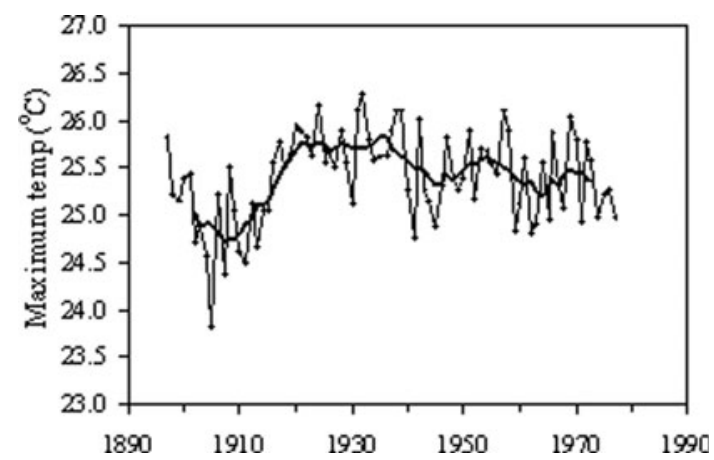

Fig. 3. Annual mean maximum air-temperature trend at the Indian Embassy, Kathmandu, from 1897 to 1977 . The 10 year running mean is shown with a thick line.

are a result of changes in individual climate parameters. We have therefore used the ELA-climate model of Kuhn (1989) to estimate the climatic changes required to explain the observed ELA fluctuations.

The ELA-climate model requires the lapse rates for temperature and precipitation, the gradients in latent heat and radiation, and the bulk transfer coefficient for sensible heat to be specified. The mean lapse rate of air temperature in the Langtang valley $\left(0.0053^{\circ} \mathrm{Cm}^{-1}\right.$ : Fujita and others, 1997 ) is used for glaciers in the Langtang region. The lapse rate of air temperature in the Shorong Himal $\left(0.006^{\circ} \mathrm{C} \mathrm{m}^{-1}\right.$ (Ageta and others, 1980)) is used for all other regions. There is a tendency for precipitation to increase with altitude in the Nepalese Himalaya (Higuchi and others, 1982). Yasunari and Inoue (1978) noted that total rainfall around 5000$5500 \mathrm{~m}$ in the Khumbu region was about four times higher than at Lhajung station $\left(27^{\circ} 53^{\prime} \mathrm{N}, 86^{\circ} 50^{\prime} \mathrm{E} ; 4420\right.$ ma.s.l.) during the 1976 summer monsoon season. In the Langtang valley, the rainy-season precipitation at $5000 \mathrm{~m}$ a.s.l. was 1.3 times larger than at $4000 \mathrm{~m}$ a.s.l. (Seko, 1987). We have therefore assumed a precipitation gradient of $0.2 \mathrm{~mm} \mathrm{~m}^{-1}$ for eastern Nepal. If the accumulation gradient is lower than is assumed (remembering the gradient can be negative as well, with precipitation decreasing with elevation), then the temperature changes calculated by the model will be too large. Compared to the mid-latitudes, this lower accumulation gradient increases the sensitivity of ELA to temperature changes. The gradients of latent heat and radiation balance with altitude are assumed to be zero. The bulk transfer coefficient for sensible heat is assumed to be the minimum value $\left(5.8 \mathrm{~W} \mathrm{~m}^{-2} \mathrm{~K}^{-1}\right)$ given in Kuhn (1989).

The results from this modelling exercise are similar for all four regions of eastern Nepal (Table 2). That is, the change in ELA could be produced by either a temperature change of $0.72-0.91^{\circ} \mathrm{C}$, a decrease in precipitation of $129-164 \mathrm{~mm} \mathrm{a}^{-1}$ or an increase in effective global radiation of 4.16$5.29 \mathrm{~W} \mathrm{~m}^{-2}$. The limited observations of precipitation indicate no significant change in precipitation during the historic period, either at low-elevation (i.e. Kathmandu) or at high-elevation (i.e. Langtang) sites. A decrease of 129$164 \mathrm{~mm} \mathrm{a}^{-1}$ should have been apparent in these records. Thus, it seems unlikely that decreased precipitation is responsible for the observed changes in ELA. There are no long-term data on radiation from eastern $\mathrm{Nepal}$, so we are unable to evaluate the possibility that the observed changes are caused by an increase in global radiation, except to say 


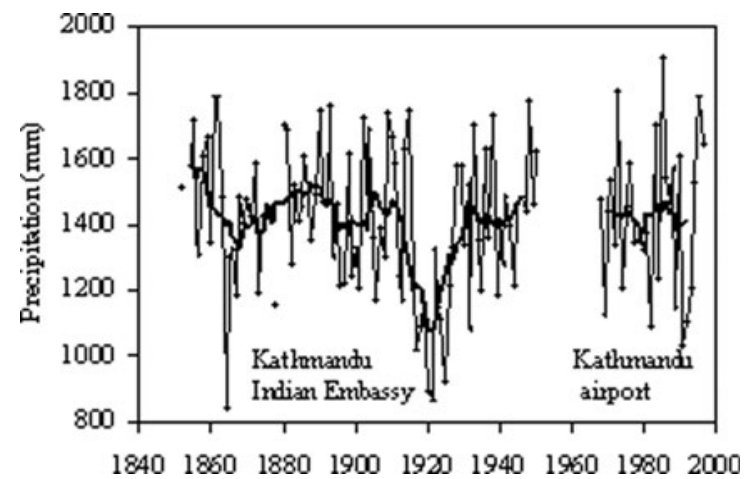

Fig. 4. Annual precipitation trend at the Indian Embassy, Kathmandu, (1852-1952) and Kathmandu airport (1968-96). The 10 year running mean is shown with a thick line.

that the magnitude of the change $\left(4.16-5.29 \mathrm{~W} \mathrm{~m}^{-2}\right)$ is implausibly large. However, the change in temperature required to explain the observed changes in ELA between the end of the LIA and 1992 is entirely consistent with the instrumental records. The increase in temperature in the Kathmandu area between 1897 and 1994 is of the order of $1.25^{\circ} \mathrm{C}$ (Fig. 3; Shrestha and others, 1999), and this warming alone could produce the observed regional shifts in the ELA between the end of the LIA and 1992. Shrestha and others (1999) found that the warming in Kathmandu between 1977 and 1994 was more limited than the warming in the highelevation regions of Nepal (Middle Mountains and Himalaya) compared to southern regions (Siwalik and Terai). Thus, there seems to be little difficulty in imagining that sufficient warming took place at the elevation of the glaciers to account for the observed change in ELA. Radiation definitely provides a major contribution to the warming, but due to the lack of radiation data we could not establish its contribution quantitatively.

\section{DISCUSSION}

The main sources of error in the present study are the assumption of the snowline altitude as an ELA in 1992 (not steady-state ELA) and the assumption that the head of the glacier at the end of the LIA and in 1959 is the same as in 1992. These errors are due to the limitations of the available data. The other error may be due to the assumption that the LIA ended in 1815 . We have shown that the average yearly rise in ELA in eastern Nepal between 1959 and 1992 $\left(0.76 \mathrm{~m} \mathrm{a}^{-1}\right)$ is significantly larger than the average yearly rise between the LIA and $1959\left(0.38 \mathrm{~m} \mathrm{a}^{-1}\right)$. The large difference

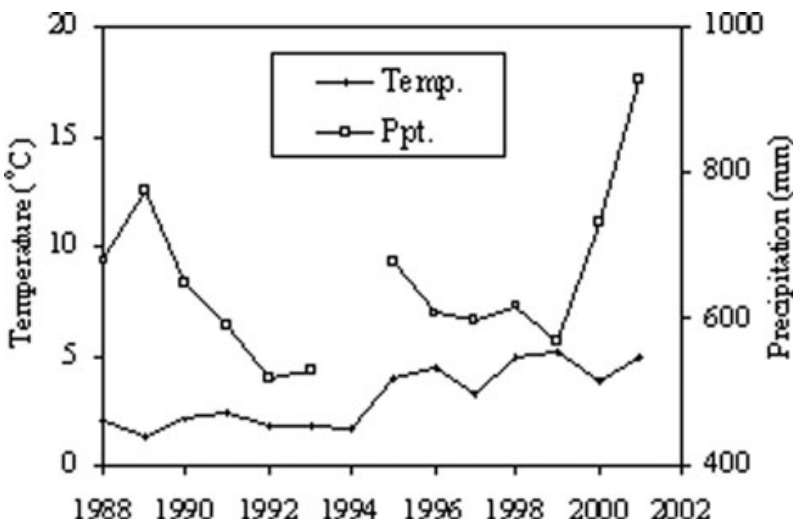

Fig. 5. Annual mean air temperature and total precipitation distribution at Kyangjing hydro-meteorological station from 1988 to 2001.

in the rates between the two periods is, to some extent, dependent on the assumption that the LIA ended in AD 1815. Using the date for the end of the LIA globally (AD 1850) would result in an estimated average rise between the LIA and 1959 of $0.50 \mathrm{ma}^{-1}$ (std dev. 0.38), and a less pronounced difference between the rates in the earlier and later periods. Nevertheless, even these estimates would still be consistent with an increase in the rate of glacier retreat after 1959. Furthermore, our findings of a significant increase in glacier retreat in recent decades are consistent with short-term observations from the region. Fujita and others (1998) showed that terminus retreat and surface lowering in the Langtang region was more rapid in the 1990s than in the 1980s. Yamada and others (1992) found that the retreat rate of some glaciers in the Khumbu region was accelerated during the 1980s compared to the 1970s. Previous observations of glacier termini fluctuations in the Nepalese Himalaya are given in Table 3 (Fushimi and Ohata, 1980; Yamada and others, 1992; Kadota, 1997; Fujita and others, 1998, 2001). The surface lowering rate of Glacier AX010 between 1978 and 1991 was $0.71 \mathrm{~m} \mathrm{a}^{-1}$ and increased to $1.14 \mathrm{ma}^{-1}$ between 1991 and 1996 (Kadota, 1997). Similarly, the surface lowering rate of Yala Glacier was $0.31 \mathrm{~m} \mathrm{a}^{-1}$ between 1982 and 1994 and increased to $1.05 \mathrm{ma}^{-1}$ between 1994 and 1996 (Fujita and others, 1998). Thus, these individual studies confirm our conclusion that the glaciers in the Nepalese Himalaya have been retreating more rapidly in the recent past than in the earlier parts of the industrial era.

We have suggested that the increased rates of retreat in recent decades are mainly due to increased air temperature. Seko and Takahashi (1991) have suggested that glacier

Table 2. Spatial differences in $\triangle E L A$ of debris-free glaciers from the end of the LIA to 1992 in the Kanchanjunga, Khumbu, Rolwaling and Langtang regions and eastern Nepal, and alternatively required values for differences in air temperature $\left(\delta T_{\mathrm{a}}\right)$, accumulation $(\delta c)$ and effective global radiation $(\delta G)$

\begin{tabular}{lccccc}
\hline & Kanchanjunga & Khumbu & Rolwaling & Langtang & Eastern Nepal \\
\hline$\Delta \mathrm{ELA}(\mathrm{m})$ & 66 & 76 & 84 & 77 & 75 \\
$\delta T_{\mathrm{a}}\left({ }^{\circ} \mathrm{C}\right)$ & +0.72 & +0.83 & +0.91 & +0.78 & +0.81 \\
$\delta C\left(\mathrm{~mm} \mathrm{a}^{-1}\right)$ & -129 & -149 & -164 & -141 & -147 \\
$\delta G\left(\mathrm{~W} \mathrm{~m}^{-2}\right)$ & +4.16 & +4.79 & +5.29 & +4.54 & +4.72 \\
\hline
\end{tabular}


Table 3. Terminus retreat rates of glaciers in the Khumbu, Rolwaling and Langtang regions from the 1970 s to the present. Positive values denote advance of the terminus position

\begin{tabular}{|c|c|c|c|}
\hline Region & Glacier & Duration & $\begin{array}{l}\text { Retreat rate } \\
\qquad \mathrm{m} \mathrm{a}^{-1}\end{array}$ \\
\hline Khumbu & DX080 & $\begin{array}{l}1976-89 \\
1990-95\end{array}$ & $\begin{array}{l}-4.6 \\
-4.9\end{array}$ \\
\hline & EB050 & $\begin{array}{l}1976-78 \\
1977-89\end{array}$ & $\begin{array}{c}-0.93 \text { to }-1.79 \\
-2.28\end{array}$ \\
\hline & ED010 & $\begin{array}{l}1974-78 \\
1978-89\end{array}$ & $\begin{array}{c}-0.6 \text { to }-1.2 \\
-2.4\end{array}$ \\
\hline & Kongma (ED020) & $\begin{array}{l}1970-76 \\
1976-78 \\
1979-89\end{array}$ & $\begin{array}{l}-5.0 \\
-2.6 \\
-2.9\end{array}$ \\
\hline & Chukhung (ED580) & $\begin{array}{l}1976-78 \\
1978-89\end{array}$ & $\begin{array}{c}+3.5 \text { to } 6.8 \text { (centre) } \\
+2.6 \text { (left part) } \\
-9.1 \text { (approx.) }\end{array}$ \\
\hline Rolwaling & AX010 & $\begin{array}{l}\text { 1978-89 } \\
1989-95 \\
1996-99 \\
1999-2004\end{array}$ & $\begin{array}{l}-2.7 \\
-6.7 \\
-30 \\
-14\end{array}$ \\
\hline Langtang & Yala & $\begin{array}{l}1982-87 \\
1987-89 \\
1989-94 \\
1994-96\end{array}$ & $\begin{array}{l}+0.5 \\
-3.4 \\
-3.9 \\
-4.3\end{array}$ \\
\hline
\end{tabular}

fluctuations in the Khumbu region in the 1980s followed the fluctuations in air temperature more closely than changes in precipitation. Kayastha and others (2005) also found increased river discharge during the 1990s in the glacierized Langtang and Lirung Khola basins as a result of increased glacier melting with increased air temperature. Precipitation did not change significantly in the 1990s. Thus, it seems likely that increase in air temperature is the main reason for glacier retreat and hence the shift of the ELA upwards in the Nepalese Himalaya.

We have shown that the magnitude of the change in ELA varies with aspect. This finding is consistent with a recent study of the changes in tropical snowline elevation between the Last Glacial Maximum (LGM) and the present (Mark and others, 2005), which showed that $\triangle E L A$ within the region was strongly influenced by aspect. In the Himalaya, they have found that the largest changes in ELA occurred on westand southwest-facing slopes. However, Mark and others (2005) found that most of the variability in the $\Delta E L A$ between the LGM and the present was explained by headwall elevation, a proxy for the size of the catchment contributing to the glacier and the glacier slope. We have been unable to show a similar relationship for more recent glacier fluctuations. Given the strength of the relationship between headwall altitude and $\triangle E L A$ shown by Mark and others (2005), we suggest our failure to identify such a relationship in the present study reflects the fact that the differences in the size and slope of the glaciers considered in the present study are rather small.

\section{CONCLUSIONS}

The estimated ELAs for 1992 for debris-free glaciers in eastern Nepal range from $5300 \mathrm{~m}$ in Langtang to $5600 \mathrm{~m}$ in Khumbu. The $\triangle E L A s$ of debris-free glaciers between the end of the LIA and 1992, and between 1959 and 1992, in eastern Nepal are 79 and $25 \mathrm{~m}$, respectively. The most probable cause of these changes in ELA is increased air temperature. This study confirms that the rate of average ELA rise of glaciers between 1959 and 1992 is much more than the ELA rise between the end of the LIA and 1992. The higher rate of the ELA rise between 1959 and 1992 is attributed to the significant warming that occurred after the 1970 s at higher altitudes in Nepal. The ELA-climate model and a long climatological record of Kathmandu indicate that the air-temperature increase in the second part of the 20th century can explain the observed ELA changes in eastern Nepal. The fact that the magnitude of the change in ELA varies with aspect, however, shows that other factors (e.g. precipitation or radiation receipts) may amplify the response to this warming.

\section{ACKNOWLEDGEMENTS}

Postdoctoral support for R.B. Kayastha was provided by the Max Planck Institute for Biogeochemistry, Jena. We thank K. Asahi of Hokkaido University for providing inventory data, and B. Mark of Ohio State University for valuable comments on the manuscript.

\section{REFERENCES}

Ageta, Y. and K. Higuchi. 1984. Estimation of mass balance components of a summer-accumulation type glacier in the Nepal Himalaya. Geogr. Ann., 66A(3), 249-255.

Ageta, Y., T. Ohata, Y. Tanaka, K. Ikegami and K. Higuchi. 1980. Mass balance of glacier AX010 in Shorong Himal, east Nepal during the summer monsoon season. Seppyo, J. Jpn. Soc. Snow Ice, 41, 34-41.

Asahi, K. 1999. Data on inventoried glaciers and its distribution in the eastern part of Nepal Himalaya. Data Report 2 (1994-1998), Cryosphere Research in the Himalaya (CREH). Nagoya, Nagoya University. Institute for Hydrospheric-Atmospheric Sciences; Kathmandu: HM Government of Nepal, Department of Hydrology and Meteorology.

Benn, D.I., L.A. Owen, H.A. Osmaston, G.O. Seltzer, S.C. Porter and B. Mark. 2005. Reconstruction of equilibrium-line altitudes for tropical and sub-tropical glaciers. Quat. Int., 138-139, 8-21.

Bradley, R.S. and P.D. Jones. 1992. When was the "Little Ice Age"? In Mikami, T., ed. International Symposium on the Little Ice Age Climate, 25-28 September 1991, Tokyo. Proceedings. Tokyo, Tokyo Metropolitan University, 1-4.

Cook, E.R., P.J. Krusic and P.D. Jones. 2003. Dendroclimatic signals in long tree-ring chronologies from the Himalayas of Nepal. Int. J. Climatol., 23(7), 707-732.

Dyurgerov, M.B. and M.F. Meier. 1997. Mass balance of mountain and subpolar glaciers: a new global assessment for 1961-1990. Arct. Alp. Res., 29(4), 379-391.

Eguchi, T. 1994. Regional differences in precipitation in the globe, the Indo-China Peninsula and the Bhutan Himalayas. (Doctoral thesis, University of Tokyo.)

Fitzharris, B.B., P.M.B. Föhn and W. Haeberli. 1996. The cryosphere: changes and their impacts. In Watson, R.T., M.C. Zinyowera and R.H. Moss, eds. Climate change 1995: impacts, adaptations and mitigation of climate change: scientific-technical analyses. Contribution of Working Group II to the Second Assessment Report of the Intergovernmental Panel on Climate Change. Cambridge, etc., Cambridge University Press, 241-265. 
Fujita, K., A. Sakai and T.B. Chhetri. 1997. Meteorological observation in Langtang valley, Nepal Himalaya. Bull. Glacier Res. 15, 71-78.

Fujita, K., N. Takeuchi and K. Seko. 1998. Glaciological observations of Yala Glacier in Langtang Valley, Nepal Himalayas, 1994 and 1996. Bull. Glacier Res. 16, 75-81.

Fujita, K., T. Kadota, B. Rana, R.B. Kayastha and Y. Ageta. 2001. Shrinkage of Glacier AX010 in Shorong region, Nepal Himalayas in the 1990s. Bull. Glaciol. Res. 18, 51-54.

Fushimi, H. and T. Ohata. 1980. Fluctuations of glaciers from 1970 to 1978 in the Khumbu Himal, east Nepal. Seppyo, J. Jpn. Soc. Snow Ice, 41, 71-81.

Haeberli, W. and M. Beniston. 1998. Climate change and its impacts on glaciers and permafrost in the Alps. Ambio, 27(4), 258-265.

Hastenrath, S. 1991. Climate dynamics of the tropics. Dordrecht, etc., Kluwer Academic Publishers.

Hastenrath, S. and L. Greischar. 1997. Glacier recession on Kilimanjaro, East Africa, 1912-89. J. Glaciol., 43(145), 455-459.

Higuchi, K. and 8 others. 1980. Glacier inventory in the Dudh Kosi region, east Nepal. IAHS Publ. 126 (Workshop at Reideralp 1978 - World Glacier Inventory), 95-103.

Higuchi, K., Y. Ageta, T. Yasunari and J. Inoue. 1982. Characteristics of precipitation during the monsoon season in high-mountain areas of the Nepal Himalaya. IAHS Publ. 138 (Symposium at Exeter 1982 - Hydrological Aspects of Alpine and High Mountain Areas), 21-30.

Houghton, J.T. and 7 others, eds. 2001. Climate change 2001: the scientific basis. Contribution of Working Group I to the Third Assessment Report of the Intergovernmental Panel on Climate Change. Cambridge, etc., Cambridge University Press.

Kadota, T. 1997. Study on the relation between climate and recent shrinkage of small glaciers in the Nepal Himalayas. (DSc thesis, Nagoya University.)

Kadota, T., K. Seko, and Y. Ageta. 1993. Shrinkage of glacier AX010 since 1978, Shorong Himal, east Nepal. IAHS Publ. 218 (Symposium at Kathmandu 1992 - Snow and Glacier Hydrology), 145-154.

Kaser, G. and H. Osmaston. 2002. Tropical glaciers. Cambridge, etc., Cambridge University Press.

Kayastha, R.B., Y. Takeuchi, M. Nakawo and Y. Ageta. 2000. Practical prediction of ice melting beneath various thickness of debris cover on Khumbu Glacier, Nepal using a positive degreeday factor. IAHS Publ. 264 (Symposium at Seattle 2000 - DebrisCovered Glaciers), 71-81.

Kayastha, R.B., Y. Ageta and K. Fujita. 2005. Use of positive degreeday methods for calculating snow and ice melting and discharge in glacierized basins in the Langtang Valley, Central Nepal. In De Jong, C., D. Collins and R. Ranzi, eds. Climate and hydrology in mountain areas. Chichester, John Wiley and Sons.

Kuhn, M. 1989. The response of the equilibrium line altitude to climatic fluctuations: theory and observations. In Oerlemans, J., ed. Glacier fluctuations and climatic change. Dordrecht, etc., Kluwer Academic Publishers, 407-417.

Mark, B.G., S.P. Harrison, A. Spessa, M. New, D.J.A. Evans and K.F. Helmens. 2005. Tropical snowline changes at the last glacial maximum: a global assessment. Quat. Int., 138-139, 168-201.

Meierding, T.C. 1982. Late Pleistocene glacial equilibrium-line altitudes in the Colorado Front Range: a comparison of methods. Quat. Res., 18(3), 289-310.
Miller, M.M. 1989. Comparative accumulation regimes on Himalayan and Alaskan neves and the issue of global warming. In Miller, M.M. and R.A. Marston, eds. Environment and society in the Manaslu-Ganesh region of the central Nepal Himalaya: a final report of the 1987 Manaslu-Ganesh Expedition. Moscow, ID, University of Idaho. Foundation for Glacier and Environmental Research, 89-96.

Miller, M.M. and R.A. Marston. 1989. Glacial response to climate change and epeirogeny in the Nepalese Himalaya. In Miller, M.M. and R.A. Marston, eds. Environment and society in the Manaslu-Ganesh region of the central Nepal Himalaya: a final report of the 1987 Manaslu-Ganesh Expedition. Moscow, ID, University of Idaho. Foundation for Glacier and Environmental Research, 65-88.

Nakawo, M. and G.J. Young. 1982. Estimate of glacier ablation under a debris layer from surface temperature and meteorological variables. J. Glaciol., 28(98), 29-34.

Nepal: Department of Hydrology and Meteorology (DHM). 1993. Snow and glacier hydrology year book 1993. Kathmandu, HM Government of Nepal. Department of Hydrology and Meteorology.

Nepal: Department of Irrigation, Hydrology and Meteorology. 1977. Climatological records of Nepal. Vols. I-III. Kathmandu, HM Government of Nepal. Department of Irrigation, Hydrology and Meteorology.

Oerlemans, J. 1994. Quantifying global warming from the retreat of glaciers. Science, 264(5156), 243-245.

Ono, Y. 1985. Recent fluctuations of the Yala (Dakpatsen) glacier, Langtang Himal, reconstructed from annual moraine ridges. Z. Gletscherkd. Glazialgeol., 21, 251-258.

Østrem, G. 1959. Ice melting under a thin layer of moraine, and the existence of ice cores in moraine ridges. Geogr. Ann., 41(4), 228-230.

Seko, K. 1987. Seasonal variation of altitudinal dependence of precipitation in Langtang valley, Nepal Himalayas. Bull. Glacier Res. 5, 41-47.

Seko, K. and S. Takahashi. 1991. Characteristics of winter precipitation and its effect on glaciers in the Nepal Himalayas. Bull. Glacier Res. 9, 9-16.

Shiraiwa, T. and T. Watanabe. 1991. Late Quaternary glacial fluctuations in the Langtang Valley, Nepal Himalaya, reconstructed by relative dating methods. Arct. Antarct. Alp. Res., 23(4), 404-416.

Shrestha, A.B., C.P. Wake, P.A. Mayewski and J.E. Dibb. 1999. Maximum temperature trends in the Himalaya and its vicinity: an analysis based on temperature records from Nepal for the period 1971-1994. J. Climate, 12(9), 2775-2786.

Warrick, R.A., C. le Provost, M.F. Meier, J. Oerlemans and P.L. Woodworth. 1996. Changes in sea level. In Houghton, J.T., L.G.M. Filho, B.A. Callander, N. Harris, A. Kattenberg and K. Maskell, eds. Climate change 1995: the science of climate change. Cambridge, etc., Cambridge University Press, 359-405.

Yamada, T. and 7 others. 1992. Fluctuations of the glaciers from the 1970s to 1989 in the Khumbu, Shorong and Langtang regions, Nepal Himalayas. Bull. Glacier Res. 10, 11-19.

Yasunari, T. 1976. Seasonal weather variations in Khumbu Himal. Seppyo, J. Jpn. Soc. Snow Ice, 38, Special Issue, 74-84.

Yasunari, T. and J. Inoue. 1978. Characteristics of monsoonal precipitation around peaks and ridges in Shorong and Khumbu Himal. Seppyo, J. Jpn. Soc. Snow Ice, 40, Special Issue, 26-32. 